\title{
Archives and Transitional Justice in Chile: A Crucial Relationship
}

\section{Anita Ferrara ${ }^{1}$ (D)}

Accepted: 18 June 2021/ Published online: 23 July 2021

(C) The Author(s) 2021

\begin{abstract}
The article, through the case study of Chile, explores the interconnections between archives, human rights and transitional justice. Chile represents a unique case globally for the early creation of thousands of records documenting the human rights violations committed under Pinochet's 17-year dictatorship. In post-Pinochet Chile, the human rights archives have provided extremely important sources of evidence that have proven crucial in the development of transitional justice mechanisms. Truth commissions have, in turn, created their own archives, which have strongly contributed to later processes of reparation, justice and memory. The article aims to develop a better understanding of the multiple roles that archives have played as tools for achieving truth, justice and reparation over the long transitional period in Chile. The article argues that a combination of several factors and the intervention of different actors led to the archives having a significant impact in the development of subsequent transitional justice mechanisms.
\end{abstract}

Keywords Archives and transitional justice $\cdot$ Source of evidence $\cdot$ Archives and memory $\cdot$ Transitional justice in Chile $\cdot$ Memory struggle

\section{Introduction}

The relationship between archives and transitional justice mechanisms remains an under-researched field of inquiry. While in the past decade the topic of archives and human rights has received increasing attention from scholars, archivists and civil society, the interaction between archives and transitional justice (TJ) in post-conflict and post-authoritarian societies deserves further analysis and investigation.

Transitional justice is the process through which states and societies address the legacy of gross and systematic human rights violations, in order to facilitate

Anita Ferrara

anita.ferrara@nuigalway.ie; anitaferrara@gmail.com

1 Irish Centre for Human Rights, School of Law, National University of Ireland, University Road, Galway, Ireland 
transitions from authoritarian regimes and conflicts to democracy and peace. The main mechanisms used to achieve these objectives include, but are not limited to' truth commissions, trials, reparations, memorialisation initiatives, grassroots reconciliation practices and guarantees of non-repetition.

Human rights archives have been broadly defined in the literature as records that document egregious human rights violations everywhere (Caswell 2014). Jelin and Da Silva Catela have grouped human rights archives into three main categories: archives of repressive institutions, such as secret agencies, police and military services; archives of human rights organisations and victims' organisations who opposed and resisted the repressive regimes; and finally the archives of courts, truth commissions and memory sites created to deal with the legacy of violations committed in the past (Da Silva Catela and Jelin 2002).

While in the literature different types of archives documenting human rights violations have been included under the umbrella of 'human rights archives,' this article claims that there should be more definitional clarity around the different sets of archives documenting violent and systemic abuse of power. This article defines 'human rights archives' as those created and owned by civil society groups, including but not limited to human rights organisations, victims' groups, and religious groups that systematically monitor and collect evidence of human rights violations. In turn, 'transitional justice archives' are those archives left behind by transitional justice mechanisms created to deal with the legacy of past atrocities such as truth commissions, courts and memorialisation initiatives.

Even though human rights archives and TJ archives both document human rights violations, it is important to highlight some of the aspects that differentiate them.

First, a temporal factor : human rights archives are usually created while the violations are actually taking place, while TJ archives are created some time after the violations have been committed. Furthermore, while human rights archives are mostly private archives and privately owned, those created by TJ mechanisms are usually state-owned even though in many cases, the former have dramatically contributed to the formation of the latter. These differences have important implications in terms of safekeeping practices, management and access policies. Archives of repressive institutions, security and secret agencies are not analysed in this article as in Chile they have remained mostly secret or have been destroyed, thus contributing very little to the process of transitional justice.

The theoretical framework for this article emerges from the literature on the instrumental role of archives in societies coming to terms with widespread human rights violations (Alberch I Fugueras 2008a; Baumgartner et al. 2016; Caswell 2010; Harris 2014; Weld 2014).

Scholars and practitioners have devoted increasing attention to the role of archives as instruments of human rights protection and accountability (BlancoRivera 2012), vehicles of collective memory (Da Silva Catela and Jelin 2002; Harris 2002; Schwartz and Cook 2002) and as mechanisms of social justice (Duff et al. 2013; Jimerson 2007; Strauss 2015).

Quintana's report highlighted the crucial role of human rights archives for achieving a set of collective and individual rights (Quintana 2009. In addition, the UN Principles to Combat Impunity claim that archives play a fundamental role in 
realising the right to truth, justice and reparation (UNHCHR 2005). Moreover, the experience of many transitional countries is increasingly showing that demands for truth, justice and memory are closely linked to people's ability to access documents and records. Hence, several organisationshave conducted important research on the issues of preservation, access and safekeeping archives (Swisspeace; International Council on Archives). Beyond having a role in human rights protection and accountability, archives are increasingly playing a role in building a country's collective memory and are often conceptualised as independent 'memory spaces' themselves. For Pierre Nora, archives contribute to the open-ended process of memory creation around a recent past and are situated amongst objects/artefacts that provide spaces for contesting the past through dynamic and infinite processes (Ketelaar 2008; Nora 1989).

Despite the increasing recognition of the multiple roles that archives play in transitional contexts, the interconnections between transitional justice and archives have not yet been conceptualised and/or fully explored. Questions related to what factors contribute to the activation of the archives during transitions (Ketelaar 2001), ${ }^{1}$ how and under what circumstances archives are used, to what extent and duration, deserve further investigation.

This article, through the case study of Chile, furthers the debates on the relationship between archives and transitional justice and analyses the multiple, varied and unexpected ways in which selected collections of archives have contributed to and interacted with subsequent transitional justice mechanisms in different moments of the long transitional period.

The article offers an original contribution aimed at developing a better understanding of the interaction between the archives and transitional justice mechanisms in two ways: First, it traces the multiple and sometimes-unexpected roles played by human rights and truth commissions' archives over a transitional period lasting 40 years. Second, it investigates the factors that facilitated the interaction between archives and later transitional justice mechanisms.

The article finds that the archives alone were a necessary, but not a sufficient condition to contribute to the broader process of transitional justice. The study claims that the combination of several factors, including contextual dynamics, intervention and motivation of different actors and timing, have activated the archives analysed in this article, thus facilitating their contribution to the realisation of truth, justice and reparation.

In the past few years, there has been a greater focus in the literature on the archives in Chile, which has mostly centred on the modes of production, preservation and access to the numerous archives documenting the violations perpetrated by Augusto Pinochet's dictatorship. Bernasconi's work provides an in-depth exploration of the complex processes of registration, organisation and categorisation of the Vicariate archives during the dictatorship (Bernasconi 2019). The latest research on the archives is dedicated to the complex relationship between archives and memory (Acuña Flores et al. 2016).

\footnotetext{
1 Activation is a concept originally used by Ketelaar in relation to the infinite possibilities of an archive.
} 
Nonetheless, very little has been written on the role played by both Chilean truth commissions' archives in advancing subsequent transitional justice mechanisms and no study has analysed which factors, or combination thereof, facilitated the uses of the archives in the subsequent years. In addition, this study provides a comprehensive overview of the changing and multiple roles that different sets of archives have played in pursuing truth, justice, reparations and memory during a period spanning more than four decades. Finally, the temporal distance of the Chilean case offers important insights and lessons on the interconnection between archives and transitional justice from a long-term perspective. Time itself, as the article shows, becomes a critical factor determining whether an archive can be discovered and re-discovered in different spaces for different purposes.

\section{Methods}

The methodology used in this research is largely empirical and is based upon a combination of qualitative data collection methods including fieldwork research carried out at multiple intervals over many years, archival research, one-on-one interviews, personal observation, oral history and secondary sources.

Semi-structured interviews have been conducted with human right lawyers, members of human rights organisations, state actors, judges, academics and personnel of state agencies in charge of the archives, such as the National Institute of Human Rights, the Human Rights Programme and the Museum of Memory. The interviews have been transcribed and a deductive thematic analysis was carried out according to the following themes: uses of archival sources, methods of classification and systematisation, goals and objectives of documenting and access policies. The themes have been identified in the literature as relevant concepts to examine the relationship between archives and transitional justice and they are the most relevant to the scope of this study.

The thematic analysis was complemented by extensive analysis of both governmental documents, NGOs' reports as well as other secondary sources. In addition, NGOs' annual reports including the Observatory for Human Rights, the National Institute for Human and Rights and the Human Right programme Reports have been extensively revised. Archival sources and documents used for this article come mainly from the Vicariate of Solidarity public archive. Particular attention has been devoted to the analysis of press files, media outlets, monthly bulletins and public declarations released by multiple actors when both truth commissions were established. These sources helped the author to understand the methods of work of the truth commissions as well as the role and motivations of relevant actors in the utilisation and selection of the existing human rights archives. Finally, a selected numbers of first and second instance judgements and other judicial documents have also been extensively examined. These helped the author to explore the judicial use of the truth commissions' archives. The main findings of this study have been drawn by the triangulation of these multiple qualitative data sources. 


\section{Human rights archives}

On 11 September 1973, a rightist military coup d'état, headed by General Augusto Pinochet, brought to an end the democratically elected government of Salvador Allende. Following the coup, a four-man military junta was established, which assumed all constituent, executive and legislative powers (Decree Law N.5 11 September 1973). During the dictatorship, gross and systematic human rights violations were committed, political opponents were systematically executed or disappeared, and thousands of persons were imprisoned, tortured or exiled. ${ }^{2}$ The dictatorship was strongly challenged on its human rights record by a group of domestic organisations and by the international community. ${ }^{3}$ Within the country, the Catholic Church, other religious bodies and human rights organisations strongly opposed the dictatorship. Chief among these was the Comite de Cooperación para la Paz en Chile, COPACHI, an inter-faith organisation created in October 1973 and then replaced in 1976 by the Vicaría de la Solidaridad (Vicariate of Solidarity). Its staff, composed of lawyers, social workers and medical personnel, provided legal and social assistance to those who had suffered human rights violations under the dictatorship (Smith 1986). Other organisations became protagonists of the human rights defence: the Social Aid Foundation of the Christian Churches (FASIC), the Agrupación de Familiares Detenidos-Desaparecidos (Group of Families of the Detained Disappeared, AFDD), and the Chilean Commission of Human Rights and the Committee for the Defence and the Rights of the People (CODEPU). These civil society organisations worked together tirelessly to gather and organise a vast amount of documentation with the utmost accuracy and precision. They carefully filed, systematised and preserved the records that documented how the systematic practice of repression operated, as well as the extent and magnitude of the human rights violations committed. The way in which Chilean human rights organisations and the Catholic Church, in particular, were able to record evidence of the human rights violations while they were actually happening is what makes the Chilean case a quite unique example globally (Barahona de Brito 1997).

The main reason why these organisations were systematically collecting the information was as a form of denunciation of the state crimes (Lira 2017). The organisations wanted to document and raise awareness of the human rights violations being committed and record what was happening for future generations. The creation of the archives did not follow an archival methodology, but the documentation and

\footnotetext{
2 There is a vast literature on Chile's dictatorship and its legacy: Wright (2007), Stern (2010), Ensalaco (2000b), Valenzuela and Constable (1991), Collier and Sater (1999).

3 While the Catholic Church and other organisations started to register and document the cases of human rights violations, also the international community devoted great attention to the human rights situation in Chile. The UN, the OAS and Amnesty International strongly relied on the human rights groups' reports to activate the regional and international human rights protection mechanism, establishing one of the first cases of close cooperation between domestic and international groups in defence of human rights. 'Chilean human rights organizations came to be widely considered by the international human rights community as among the most effective groups working within a context of dictatorship' (see Report of the TRC, p. 11). This paper does not look at this early phase of registration and documentation, but it starts its analysis from the end of the dictatorship.
} 
testimonies were systematically filed and preserved in an attempt to collect evidence that could be used to punish the perpetrators in the future (Lira 2017). In the words of Elisabeth Lira, 'many perceived their collecting of elements of proof as a form of moral resistance to injustice and abuse' (Lira 2017; p.193).

All the abovementioned organisations created their own archives and records (Universidad Alberto Hurtado 2017). Their archives included different types of records, from administrative records documenting the work of the organisation to legal files, social assistance records, medical records, media archives, databases, statistics, collections of public documents of the time such as speeches and statements, legislation and any other information documenting how the repressive regime worked.

The most complete archive documenting the state terrorism is the Fundación de Documentación y Archivos de la Vicaría de la Solidaridad (Documentation and Archive Foundation of the Vicariate of Solidarity). When the Vicariate concluded its work in 1992, the Archdiocese of Santiago created the Archives Foundation as an institution that would protect and preserve the thousands of files and folders that the Vicariate of Solidarity had created over 20 years. The records contain information related to victims of the period between September 1973 and March 1990 and document all the actions the Vicariate staff undertook in the defence and promotion of human rights.

The archives of the Vicariate constitute a unique, national human rights archive including the files of 47,000 people that asked for legal assistance at the Vicariate during the dictatorship. These include copies of court records and other similar files such as habeas corpus appeals in favour of detainees and exiled, political prisoners and people who had been subjected to torture (Lowden 1995; Labbé and Tagle 2019).

The following section analyses the interconnection between the human rights archives, particularly the Vicariate archives, and the first National Commission on Truth and Reconciliation as well as the contribution the archives made to the development of other transitional justice mechanisms. The rather constrained political context that existed in the early years of the transition allowed only limited truth and reparation measures to be established. The Vicariate archives later proved to be critical for achieving both truth and reparation.

\section{The Uses of Human Rights Archives}

The Chilean National Truth and Reconciliation Commission, TRC (also known as the Rettig Commission), was created in 1990 through Supreme Decree no.355, by President Aylwin to investigate and report on the cases of enforced disappearance and political execution, committed under the Pinochet dictatorship between 1973 and $1990 .{ }^{4}$ The Chilean TRC completed its work 1 year after it was established and

\footnotetext{
${ }^{4}$ Supreme Decree N.355, Undersecretary of the Interior, 25 April 1990, Santiago de Chile.
} 
issued its final report in 1991 (known as the Rettig Report), ${ }^{5}$ documenting 3197 persons as victims of enforced disappearance and illegal execution. The Rettig Report is a massive document providing a detailed description of the main phases of the dictatorship, laid out according to the different kinds of violations committed and the methods of repression used.

In the constrained political context under which the first TRC was created, its mandate was extremely limited and it lacked subpoena powers. ${ }^{6}$ In this context, during the early information-gathering phases, the human rights organisations were asked to provide all the evidence they had gathered on the cases of the disappeared and victims who had been extra-judicially executed between 1973 and 1990.

The Chilean TRC had access to the legal archives of the Vicariate composed of 85,000 documents related to all the people the Vicariate had assisted (Vergara Low 2012). The information the Vicariate collected on the disappeared and executed was very detailed in each individual case. The Vicariate had in fact created an individual folder on each victim that had received assistance from the Vicariate. The folders included all the background information related to the circumstances of the victims' disappearance or death and the efforts made by the relatives and by the Vicariate to find out what had happened to them. The legal archive contained the records of the individual legal proceedings, including habeas corpus cases, war council proceedings, defence and denunciation briefs, stories and affidavits on the situations of human rights violations and so on. The records also included the sworn statements of relatives, eyewitness accounts of persons arrested and statements by witnesses who had been detained in the same place alongside the victims. Many people who had been arrested went to the Vicariate to give their testimony after their release, becoming irreplaceable witnesses to the detention of victims who later disappeared. It is important to remember that these files were created while the abuses were happening. This gives high value to these documents since they reported the details of the various detention centres where victims were detained or later transferred, the methods of torture they were subjected to, who they had been arrested with, the names of the perpetrators and more. It would have been very difficult to reconstruct all these factual details related to thousands of people many years after the events had happened (Vergara Low 2012).

Another organisation, the Chilean Human Rights Commission also shared its folders documenting cases of victims of political execution and disappearance, together with copies of the legal actions undertaken in their defence and the trial records. The Truth Commission crosschecked the information contained in these records against different sources verifying the reliability of the information. The Rettig Commission heavily relied upon the documentation provided by the human rights organisations and, in particular, by the Vicariate of Solidarity (Report of the Chilean National Commission on Truth and Reconciliation 1993).

Even though the Truth Commission collected extensive information from many other sources, the human rights archives, particularly the Vicariate archive, constituted

\footnotetext{
5 The Chilean TRC is commonly known as the Rettig Commission, named after President Raul Rettig.

${ }^{6}$ For a detailed analysis of the methodology and work of the Chilean TRC, see Ensalaco (2000b).
} 
an irreplaceable source of evidence upon which the Truth Commission's report and its conclusions were built. In the TRC's view, the human rights organisations had documented and monitored the human rights abuses with the utmost accuracy.

\section{The Interaction between the Vicariate archives and the National Commission on Truth and Reconciliation ('the Chilean TRC')}

This section analyses the main factors that enabled the interaction between the Vicariate archives and the Truth Commission.

First, the context of the early transition period was extremely constrained; the balance of power was very delicate and civil-military relations were very tense. The Chilean democracy of the 1990s remained constrained under the military's tutelage; far from being subject to the civilian authorities, the armed forces maintained the strong political role granted to them under the constitution and by the organic law of the armed forces, and held key positions within the institutional structure. Moreover, there was a strong alliance between the armed forces and the right-wing conservative parties, which were bent on defending the political project of the military regime. Pinochet also remained Commander-in-Chief of the Army, which guaranteed that the armed forces would not be prosecuted and that the institutional framework of the protected democracy remained intact. Finally, Pinochet and his allies still had fairly strong popular support (Fuentes 2000; Rabkin 1992).

In this context, in the earlier phases of the transition, there was strong cooperation between the Concertacion, ${ }^{7}$ the centre-left coalition party that won the first democratic elections, and the human rights movement (Barahona de Brito 1997). The human rights issue had cemented relations between the centre-left coalition of the Concertación, which placed the discourses about the past abuses and the traumatic experience of violent repression at the centre of their electoral campaign to defeat Pinochet (Barahona de Brito 1997).

The governing political parties and key human rights organisations, such as the Vicariate and the Chilean Human Rights Commission, thus shared a high degree of consensus around the establishment of a truth commission (Barahona de Brito 1997; p.110). The Vicariate of Solidarity had expressed public support for the work of the truth commission and considered it an important step towards reaching a reconciliation. This cooperation aided the process of sharing the information stored in the Vicariate archives. ${ }^{8}$

Moreover, according to a recent study the Vicariate had collated the information it possessed on the cases of persons disappeared and politically executed in a manner that enabled the information to be easily accessed by the following truth

\footnotetext{
7 The Concertacion was a multi-party coalition of the centre-left, including the Christian Democratic Party, the Socialist Party. It won the election in 1989.

8 Archival material consulted by the author at the Vicariate archives on the early years of the transition, including press files, public statements from human rights groups, political parties' leaders, Vicariate public statements during the working of the TRC.
} 
commission and by the relatives of the victims who wanted to bring their files before the TRC (Bernasconi and Lira 2019).

In addition, the truth commission members were aware of the work of the human rights organisations and fully trusted their work. ${ }^{9}$ This kind of cooperation was greatly facilitated by the presence of members of the Truth Commission that were strongly associated with the human rights movement. President Aylwin had carefully chosen the members of the commission from both sides of the political spectrum to ensure a balanced and consensus-based outcome (Otano 2006). He appointed two influential figures among the human rights community, Jose Zalaquett and Jaime Castillo Velasco. Jose Zalaquett, who actively supported the establishment of the TRC, was a former legal adviser to the Vicariate of Solidarity and had been exiled by the regime. Jaime Castillo Velasco was a former member of the Christian Democratic Party (PDC) and the president of another prominent human rights organisation, the Chilean Human Rights Commission (Otano 2006). Both had achieved recognition for their work in the defence of human rights. Their appointment as TRC Commissioners was welcomed by the human rights organisations (Otano 2006). The fact that prominent TRC members had previously been themselves protagonists of the defence of human rights during the dictatorship and were well aware of the massive amount of work carried out by civil society in recording the violations committed, facilitated the use of the human rights archives by the Rettig Commission.

Finally, when the Vicariate closed in 1992, many of the social workers and lawyers who had assisted victims at the Vicariate went to work for the Rettig Commission and the follow-up bodies that administered and delivered the reparations in the years that followed. All these people knew very well how the Vicariate archives were created and filed, and could act as mediators between all the information contained in the archives and the state agencies. The expertise of social workers and lawyers was crucial in utilising the archives to develop later transitional justice mechanisms (Johansson and Lopez 2019).

A combination of the above factors and the synergy between the truth commission and the civil society sectors facilitated the use of thousands of records collected by the Vicariate and other human rights organisations. Had these records not existed, it would have been very difficult to document in only 9 months the extent and magnitude of the violations committed over a period of 17 years. In turn, all the organisations working in defence of human rights saw for the first time their work recognised and publicly acknowledged. In the words of Elisabeth Lira, the civil society organisations had collected copious documentation with the aim to reveal the factual truth of the violations that occurred and to punish those responsible. ${ }^{10}$ The Rettig commission legitimised the work of the human rights organisations, which had previously been discredited by the regime and its allies as communist propaganda. Therefore, the truth commission members and its staff, in a context of cooperation with the civil society actors, including social workers and human rights lawyers,

\footnotetext{
9 Ibid.

10 Professor Elisabeth Lira, Universidad Alberto Hurtado, Member of the Valech Commission I and II and Roundtable Dialogue, Personal Communication, April 2021.
} 
activated the human rights archives in a complex political context that only allowed for limited truth and reparation. The analysis of data collected for this study shows that the constrained political context, the synergy of social and political actors and a high degree of trust in the newly formed Truth Commission constituted the main factors that activated the human rights archives in a way that they could contribute to the public disclosure and acknowledgment of the human rights violations committed during 17 years of dictatorship.

Many years later and in a very changed political context, the archives of the Vicariate became essential documents for the realisation of subsequent reparation and justice measures implemented in the wake of the TRC. The legal archive of the Vicariate is confidential, but it remains open to judges and governmental agencies that require these records to take further action in order to provide justice and reparations to the victims of past abuses. Judges regularly request access to the legal archives of the Vicariate of Solidarity, which has become an important source of judicial evidence in the current human rights trials (Hau et al. 2019). Finally, the individual folders containing information on each victim who had received legal or social assistance from the Vicariate constitute critical evidence needed to certify the status of 'victim' so that relatives and survivors could be granted access to reparations benefits (Vergara Low 2012). The TRC had recognised only the victims of disappearance and political execution, therefore the Vicariate Archive turned out to be an extremely reliable source of evidence to certify the status of other categories of victims of human rights violations, which were progressively recognised by the Chilean state in later years. Since the early 1990s, many reparations packages have been available and delivered by the state to different categories of victims, including the politically exonerated, returnees and others. ${ }^{11}$ The role of archives and records in facilitating the delivery of the reparations is not fully explored in this paper, as it would require a separate paper due to its extensiveness. In sum, the Vicariate archives have been fundamental in achieving a disclosure of truth in the immediate post-transition phase, andin contributing to legal justice and reparation in later years. At the time, no one could foresee that the human rights records would be the basis of all future transitional justice developments in the country. ${ }^{12}$

\section{The Rettig Commission's Archives}

Beyond the archives of the national and international human rights organisations, the Rettig Commission collected thousands of declarations from victims' relatives, witnesses and political prisoners who offered their testimony before the Commission. The Commission gathered direct testimony on around 3400 cases (Americas Watch 1991). The Commission also solicited information abroad from Chilean exiles.

The armed forces did not cooperate with the truth commission and the only relevant information sent by them was related to the armed forces members who had

\footnotetext{
11 Ferrara (2015), pp 60-64.

12 Interview with Roberto Garreton, Human Rights Lawyer, Santiago, Chile, March 2019.
} 
been killed during military confrontations. However, few military officers provided testimony. The TRC cross-checked the records obtained from the civil society organisations with the records of various governmental and public agencies, including the Civil Registry, the Electoral Registry, the National Archives, the General Comptroller's Office and the Chilean Police. Many hospitals provided medical reports, autopsies and death certificates. ${ }^{13}$ The TRC investigated carefully each individual case on which antecedents existed and opened a file, which included all the documentation related to the victim in question. ${ }^{14}$ It also created a database to track cases (Peterson 2005). The truth commission collected documentary evidencefrom a huge variety of sources collecting 217,000 pages filed in 3500 folders. ${ }^{15}$ Based on all the above records, testimonies and documents, the TRC members were able to reach a conviction on thousands of cases of enforced disappearance or political execution. The examination of each individual case was the methodology chosen to qualify the cases. Therefore, the TRC followed a methodology of classification and systematisation similar to that of the Vicariate, whereby it collated in one file all existing documentation, records and testimonies related to each victim of disappearance and extrajudicial execution. ${ }^{16}$ This practice was very successful as it not only offered the possibility of restoring the dignity of the individual victim but it also strongly aided the subsequent delivery of symbolic and material reparations.

The Rettig Commission's archives are confidential and data protection law restricted its use, but they were left open for the lawyers and judges who requested them for their investigations. ${ }^{17}$ For this reason, it is very difficult to find out about the exact content of the Rettig archives or the ways in which the Commission used all the sources of information it collected.

\section{The Uses of Rettig Archives: Reparations and Trials}

The most important direct consequence of the Chilean TRC was the delivery of reparation measures to the relatives of the victims qualified by the TRC. A follow-up body, the National Corporation on Reparation and Reconciliation (NCRR), was established in 1992 to complete the investigations on the unresolved cases of the previous TRC and to offer victims' families legal and social assistance and administer a broad programme of reparations, which included monetary pensions, health care and educational benefits. The Corporation published its final report in 1996 documenting 3197 people as victims of enforced disappearance and illegal execution (Corporacion Nacional de Reparacion y

\footnotetext{
13 Report of the Chilean TRC, vol. I, part I, p. 17.

14 Cristina Luz Garcia Gutierrez, 'Fuentes Para El Estudio De La Represion En Iberoamerica: Entre Archivos Y Centro Documentales' (paper presented at the Congreso Internacional 1810-2010: 200 anos de Iberoamerica, Santiago de Compostela, Espana).

15 Ibid.

16 Interview with Jorge Correa, Executive Secretary of the Rettig Commission. Santiago 2009.

17 Ley N. ${ }^{\circ} 19.123$ de 1992, states that the archives are confidential, except for the tribunals that need to investigate (art. 2.3).
} 
Reconciliacion 1996). More importantly, the NCRR established an archive and documentation repository with the purpose of collecting and safekeeping all the documents and information gathered by the TRC and the Corporation. These archives constituted the basis upon which different reparation programmes have been delivered in Chile to different groups of victims during the long transitional process. ${ }^{18}$ The creation of a detailed archival record containing information on each individual victim recognised by the truth commissions greatly facilitated the subsequent payment of reparations to the families of the disappeared.

When the NCRR concluded its work in 1996, all the archives and documents of the TRC and those belonging to the Corporation were passed to a new programme organised by the Ministry of Interior, called the Programme for the Continuation of Law 19.123, which later became the Human Rights Programme. Since 2001, the Human Rights Programme has played a major role in the prosecution of human rights cases and became the custodian of the archives of the Rettig Commission and its follow-up body, the Corporation. The programme has been transferred under the Ministry of Justice and currently renamed as Human Rights Programme Unit.

As shown in the following paragraphs, the importance of the preservation and systematisation of these archives under this public body only became apparent years later.

Although the Chilean TRC did not have any judicial powers, all the evidence it had collected that seemed new, useful or relevant for judicial investigations was sent to the Chilean courts shortly after it concluded its work (Report of the Chilean National Commission on Truth and Reconciliation 1993). At that time, the majority of cases originally submitted by the TRC to the courts had been dismissed by the Chilean tribunals, which had applied the Amnesty Law passed by the Pinochet government in 1978. During the early transition phase, the judiciary was reluctant to investigate the human rights violations and, despite numerous attempts by many different actors to obtain justice and accountability, few cases had progressed (Ferrara 2015). After the arrest of Pinochet in London in 1998, the political context changed dramatically in Chile and Chilean judges became more inclined to provide justice for victims' families. The Amnesty Law was reinterpreted allowing new cases to be investigated and many cases that had previously been dismissed without investigation were reopened. Moreover, after the creation of the Mesa de Diálogo (Roundtable Dialogue), ${ }^{19}$ special judges were appointed, exclusively dedicated to investigating the human rights cases. ${ }^{20}$ All this started a new phase for the human rights investigations and hundreds of

\footnotetext{
18 Again, the TRC archives have been crucial to certify the status of victims and have been accessed by state agencies to prove the status of the victims claiming reparations. As previously stated, the topic of reparations, archives and lists is very broad and contested, and requires a separate study.

19 The Mesa de Dialogo was created in 1999 to facilitate a dialogue between the armed forces, Human Rights lawyers and civil society representatives.

${ }^{20}$ Cath Collins, Post-Transitional Justice: Human Rights Trials in Chile and El Salvador (University Park, PA: Pennsylvania State University Press, 2010).
} 
cases started to progress. ${ }^{21}$ In later years, the Human Rights Programme would be empowered to initiate criminal proceedings in the cases of detained-disappeared persons and those extra-judicially executed. This strengthened the role of the Programme that became the main state agency prosecuting human rights cases. $^{22}$ It was within this context that many judges re-discovered the documentation and records contained in the truth commission's archives. After Pinochet's arrest, the archives of the truth commission reappeared on stage having acquired a new role, becoming the basis of the main prosecutorial efforts that then followed in Chile. Two former judges who were among the most important protagonists of the late justice cascade in Chile, Juan Guzmán, who first indicted Pinochet in 2001, and Alejandro Solís Muñoz, frequently requested access to the TRCs archives and records to the Human Rights Programme. This body has, over the years, played a critical role in facilitating access to the Rettig archives from investigative judges. ${ }^{23}$ Both judges stated that their cases had largely relied upon the documentary evidence contained in the TRC archives. ${ }^{24}$ They had both used the records and archives of the TRC as probative value in the human rights trials. ${ }^{25}$ In recent interviews, judges exclusively dedicated to investigating the human rights cases stated that they continue to actively use the archives of the truth commissions as probative evidence to build their cases and attach to them a great importance in the investigative phases of the proceedings. ${ }^{26}$ Judge Carrozza declared that the TRC archives are an invaluable contribution in his investigations. He claimed that the Rettig records contain witness statements and relatives' declarations, which constitute elements of proof that allows the reconstruction of the crime under examination. ${ }^{27}$ Equally, judge Cifuentes uses regularly the records of the truth commissions either to locate witnesses and/or relatives or to access the statements of those that are no longer able to testify. ${ }^{28}$ Both Judges attach great value to the archives and said that they consider the truth commissions' archives today to be even more valuable than before as the more time that passes, the more evidence is eroded and both victims and perpetrators are dying. ${ }^{29}$ It is important to remark here that the truth commission archives constitute one type of evidence, among many other sources, upon which judges rely to build their cases. Moreover, a detailed analysis of the evidentiary weight of the Rettig archives would require more attention and is outside the scope of

\footnotetext{
21 Ibid.

22 Observatory for Human Rights, Annual Human Rights Report, of the Centro de Derechos Humanos, UDP 2010. Santiago, Chile.

23 Interview with Francisco Ugas, Human Rights Lawyer and former Director Legal Department of the Human Rights Programme, April 2019.

24 Former Appellate Judge, Juan Guzman, Personal Interview. Santiago 2009.

25 Former Special Judge, Alejandro Solis, Personal Interview. Santigo 2009.

26 Personal Interviews with several investigative judges: Judge Mario Carrozza, Judge Marianela Cifuentes, Former Supreme Court Judge Milton Juica, Santiago, April 2019.

27 Personal Interview, Judge Mario Carrozza, April 2019.

28 Personal Interview Judge Cifuentes, April 2019.

29 Ibid.
} 
this article. Investigative judges actively use all the archives and records documenting the human rights violations that they can gain access to, including the Vicariate Archives and/or the armed forces archives. The Rettig archives have such great value for the progress of current investigations that former head of the legal department of the Human Rights programme, Francisco Ugas, tried to make all Rettig Commissions and Corporation archives immediately available to the courts in order to expedite the proceedings and avoid request for access to the Human Rights programme for each case under investigation. Unfortunately, this proposal nevermaterialized and there continues to be a piecemeal approach on access to these archives. ${ }^{30}$

\section{The Interaction between the Rettig Archives and Justice}

This study found that a combination of several factors might explain why the archives of the truth commission could unexpectedly become a means of accountability years later.

First, the armed forces and/or secret agencies' records have always been and still are largely inaccessible, because they have been destroyed, concealed or intentionally kept secret by former perpetrators. In this context, the value of human rights archives and the Truth Commissions' archives is enormous if one considers that in Chile, they represent the most important documentary evidence available, which reconstructs the history of repression and provides details on how the authoritarian state structures operated (Alberch I Fugueras 2008b).

Second, in the early transition phase in Chile, victims were eager to testify before the TRC and be heard by a state that had marginalised them and their traumatic experiences for far too long. At the time, they believed that nothing more would be done and therefore they provided all the information they had to the TRC. According to former judge Solis, the lack of protection from the courts caused a paradoxical situation, where the victims' families and other witnesses, after the end of the dictatorship, rushed to testify before the truth commission officers to provide all the information that they had kept on the human rights abuses. They provided the Commissioners with witnesses' names, court records and any documents they held, all of which allowed the Commission to carefully determine and prove what had happened in every case under their scrutiny.

Third, given the difficult political climate in which the Commission was established, the information received from a variety of sources was collected and systematised in a very meticulous way. The commissioners were very thorough and cautious in every single case under examination so that the chances of mistakes would be reduced to a minimum (Otano 2006). In addition, the fact that those who collected the evidence and heard the testimonies were mostly lawyers and legal assistants probably influenced the manner in which the evidence was collected and organised. The latter greatly facilitated the evidence being used in subsequent

$\overline{30}$ Interview with Francisco Ugas, April 2010. 
prosecutions. The combined result of the abovementioned aspects was reflected in the creation of thousands of documents and files which possess, as the current trials are demonstrating, a high level of reliability.

The data collected for this study shows that the probative value of archives depends on several factors, including how and when the information was collected and systematised, the manner in which testimonies were collected, the legal context in which the archives were created and the way in which they have been preserved. However, the truth commission archives alone could not have helped the subsequent prosecutions of human rights cases. The information has existed since the early 1990s but only started to be used 10 years later. In 1991, when the TRC report was delivered, the Supreme Court refused to acknowledge almost all the criticisms put forward by the report and considered it too passionate, reckless, political and biased (Centro de Estudios Públicos 1991). Years later, it was a dramatic change in attitude by the courts towards investigating human rights cases that re-activated the information collected by the truth commission. In this way, the TRC archives unexpectedly became one of the most reliable sources of evidence in the subsequent human rights trials. With the passing of time and in a profoundly different political environment, judges invoked the same information that had been available to them before but now that information acquired new life as judicial evidence.

Since 1998, in Chile, substantial progress has been made in the judicial investigation and resolution of human rights crimes, reversing the long-standing impunity that had existed in relation to these crimes. According to data provided by the courts, there are more than 1459 criminal cases ongoing for dictatorship-era human rights violations involving thousands of former military agents. This caseload is shared between 13 investigative magistrates, seven of them operating in the Greater Santiago jurisdiction. ${ }^{31}$

It is important to highlight here that the domestic courts are also archiving the documentation associated with their trials, which will be invaluable for revealing other aspects of the dictatorship that are still unknown. Courts' archives are part of the collective memory of the nation and will end up in the national archives. Finally, the judiciary's archives will provide more information on how the national jurisprudence on mass atrocity evolved over time and the extent to which there has been a dramatic shift in attitude by the judiciary as an institution towards the investigation of these crimes.

\section{The Valech Commissions' Archives}

The second official Truth Commission, the National Commission on Political Imprisonment and Torture (hereinafter the 'Valech I Commission'), was established in November 2003 to investigate the cases of torture and political imprisonment committed during the period between 1973 and 1990. The Valech I Commission produced a massive report divided into seven chapters, which documented 33,221

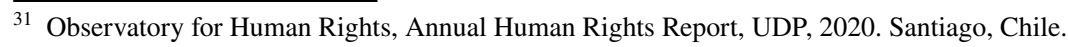


cases of arbitrary detention and certified 27,255 persons as victims of political imprisonment and torture, in line with its mandate. The Commission's report published in 2004 concluded that throughout the military regime, torture and political imprisonment were systematic and institutional policies of the state, routinely practised by the armed forces and Carabineros, as well as by the intelligence services, especially the DINA and CNI. It stands as the only truth commissions in the world to deal exclusively with surviving victims of torture and political imprisonment.

Following a work method similar to that previously used by the Chilean TRC, the Valech I Commission undertook a series of steps which included interviewing the victims of torture and political prison and collecting documents provided by them, the corroboration of this information with that provided by many other public institutions of the state, as well as with human rights organisations, victims' organisations, and eyewitness' testimonies. ${ }^{32}$ Once all the information had been collected, the commissioners proceeded by deciding which cases were eligible. ${ }^{33}$ The Commission established information-sharing agreements with several human rights organisations $^{34}$ in order to gain access to their archives (Comision Nacional sobre Prision Politca y Tortura 2004). Extensive information was also obtained from international organisations, foreign embassies and the national and international press. As with the Rettig Commission, the archives of the human rights organisations, primarily the Vicariate archives, as well as archives of trade unions were again extensively relied upon to corroborate the thousands of survivors' testimonies and witness statements. ${ }^{35}$ In a very changed political context, the Valech I Commission had access to a substantially larger amount of information from some branches of the armed forces. The latter provided the Commission with registries of detention centre locations, lists of people held in such detention camps, the period of detention and other relevant information (Comisión Nacional sobre Prisión Política y Tortura 2004).

One of the main advancements of the Valech I Commission was that it dramatically expanded upon existing information on the extent and the magnitude of torture and documented the existence of more than a thousand places throughout the country that had been used as centres of torture and detention. As with the Rettig Commission, the Valech I Commission created a single folder on each victim of torture and/or political imprisonment that testified before the Commission.

As shown above, the practice of recordkeeping, documenting and collecting evidence was a systematic practice of most human rights organisations during the years of the dictatorship. The main goal of those organisations that painstakingly filed and preserved the archives documenting human rights violations was to leave behind an irrefutable evidence of what happened. For this reason, as it happened with the

\footnotetext{
32 Informe Comisión Nacional sobre Prisión Política y Tortura (Santiago, Chile: Comisión Nacional sobre Política y Tortura, 2004), p. 80 (hereafter 'Valech Report').

33 Ibid.

34 The NGOs were the Vicariate of Solidarity, the Social Aid Foundation of Christian Churches (FASIC), the Committee for the Defence of the Rights of the People (CODEPU) and the Foundation for the Protection of Children Damaged by States of Emergency (PIDEE).

35 Interview with Professor Elisabeth Lira, April 2021.
} 
Rettig Commission, civil society organisations rushed to the Valech I Commission to deliver all the relevant information they possessed. To them, the public and official acknowledgement of the state would represent the main achievement of their tireless work of documenting. ${ }^{36}$ In addition, some members of the Valech I Commission had an extensive trajectory in defence of human rights and again they were well aware of the work carried out by human rights organisations during the dictatorship. The Commission President, Bishop Sergio Valech, was the head of the Vicariate of Solidarity during the years of the military regime and later responsible for the archives of the Vicariate. Maria Luisa Sepulveda had worked as social assistant at the Vicariate of Solidarity; Alvaro Varela was also a human rights lawyer at the Vicariate and Elisabeth Lira a renowned psychologist for her extensive work with the victims of repression during the military dictatorship. ${ }^{37}$ Therefore, the analysis of the data collected on the Valech I Commission shows that the combination of a strong civil society mobilisation, the sustained activism of survivors' groups' together with the presence of members of the Valech I Commission closely linked to the human rights organisations enabled the interaction between the human rights archives and the Valech I Commission. In 2010, the last truth-seeking initiative, the Comisión Asesora para la Calificación de Detenidos Desaparecidos, Ejecutados Políticos y Victimas de Prisión Política y la Tortura (hereinafter 'Valech II') was set up to deal with the cases of victims of political imprisonment and torture, and victims of disappearance and political execution, which had either been previously rejected or never presented before a Truth Commission. ${ }^{38}$ The Valech II Commission followed the same criteria and methodology to qualify cases as the Valech I Commission. The Valech II Commission submitted its final report in 2011, documenting a further 9795 victims of torture and political imprisonment and 30 more cases of enforced disappearance and illegal execution (Comision Asesora Presidencial 2011).

All truth commissions in Chile inherited the copious documentation that many civil society organisations had previously collected and, in many ways, they followed the same methods of work and classification criteria used by the Vicariate of Solidarity. As shown above, as the Rettig Commission created an individual file containing all the information related to each victim of disappearance and illegal execution, so too did the Valech Commissions by opening a file for every alleged victim of torture and political prison. Both Truth Commissions relied on this classification method in order to organise their records in such a waythat their findings would prove to be irrefutable. The Chilean truth commissions' reports and archives offer a vast amount of documentation, testimonies and evidence on the massive human rights violations that occurred during the dictatorship, which has been very difficult to contest. In later years, also the Valech I and II archives have played an important role as tools of justice, reparation and memory within Chilean society.

\footnotetext{
36 Ibid.

37 Ferrara, Assessing the Long-term Impact of Truth Commissions, p. 168.

38 Decreto Supremo no .43, Ministerio del Interior, 5 Febrero de 2010.
} 
The following section discusses some of the most heated debates surrounding these archives and their role in advancing the struggle to obtain truth and justice.

\section{The Interaction between the Valech Archives, Justice and Memory}

While the government had regarded the Valech I Commission and its reopening in 2011 as the closing chapters of the Chilean transitional justice process, the archives they created have become a source of controversy and contention since the Valech I Commission concluded its work in 2004. The Valech I and II archives have sparked a national debate, which mobilised multiple actors around different issues related to the opening, access, ownership and role of these archives.

In contrast to the Rettig archives, a law regulating access to the Valech I archives established that all testimonies, documents and evidence collected by the Valech I Commission were confidential and could not be disclosed to the public for 50 years nor used by the courts. ${ }^{39}$ While a draconian secrecy law surrounded the Valech I archives, the law creating the Valech II Commission established a different regime of confidentiality, which established a reservation rather than a full secrecy clause. ${ }^{40}$

The strict confidentiality of the Valech I archives had two consequences: first, it had the immediate effect of curtailing the relationship between these archives and the ability to use them to obtain justice. In contrast to the increasingly judicial role of the Rettig archives, the judicial impact of the Valech I archives was severely limited from the start. ${ }^{41}$

Second, it slowly sparked a debate within Chilean society on the importance of having access to the records documenting past atrocities in order to challenge the legacy of authoritarianism that is still present in Chilean institutions (Meza Lopehandia 2016). Several actors from civil society, primarily survivors of torture, have engaged in a prolonged struggle to gain access to the archives of the Valech I and II Commissions. Other official bodies including the National Institute for Human Rights, the Comptroller General Office of the Republic (Contraloria General del Estado) and the courts have played a role in this battle. According to many survivors of torture, the secrecy surrounding the Valech archives is not there to protect the confidentiality of the victims but to shield the perpetrators from justice. Although the law prevents the use of the Valech I archive in court, a group of survivors of torture challenged the secrecy of the archives through all the legal and political avenues open to them. In 2015, Popular Declassification (DP), a political-artistic collective was created to demand the declassification of the Valech I archives and to guarantee that survivors who testified before the Valech Commissions could gain access to their own documents (Campos and Sáez. After a legal battle won by the

\footnotetext{
39 Ley n.19.992, 24 Diciembre de 2004, Titulo IV, articulo 15.

40 Interview with Leonardo Urrutia, Head of Memory, Archive and Documentation Departnent, National Institute of Human Rights. NIHR, Santiago, March 2019.

41 The state has, on many occasions, declared that the confidentiality clause established for the Valech I archives was essential for the success of the Valech Commission and represented a formal commitment by the Government to the victims who gave their testimony before the Commission.
} 
Declassification Movement, the NationalInstitute of Human Rights (NIHR), currently the legal custodian of the Valech I and II archives, started to provide to every survivor on request, a copy of their individual file, including all the documentation related to their case. In this way, former political prisoners can bring their documentation to the courts and demand the opening of an investigation. However, the NIHR took the decision to cross out all the information contained in the individual file that is related to third parties (victims or witnesses' declarations contained in the same file). While the decision to cross out certain information from the individual folders has been contested, in the words of Leonardo Urrutia, it protects the rights to privacy of those individuals who never gave their consensus to publicly disclose their testimonies. It is relevant to note that the NIHR does not delete any information related to alleged torturers or perpetrators. ${ }^{42}$ The NIHR has frequently expressed concern about the secret nature of the archives and often requested the Government and the National Congress to lift the 50 years' secrecy clause, at least for the courts, in order to respect international standards regarding access to information and the right to truth (Fries 2015). Moreover, the courts' lack of access to the Valech I and II archives has been the subject of at least five legal opinions of the Comptroller General Office of the Republic (CGR) (Meza Lopehandia 2016). After interpreting an opinion delivered by the Comptroller General Office, the NIHR has decided to provide only the records of the Valech II Commission to the courts when the latter request access to them (Instituto Nacional de Derechos Humanos 2014). ${ }^{43}$ However, the NIHR pointed out that lack of uniformity in the management of the antecedents of the truth commissions 'infringe the principle of equality and non-discrimination', because in some cases the judges do have access to those records (Rettig and Valech II) but not in others (Valech I) (Instituto Nacional de Derechos Humanos 2014; Meza Lopehandia 2016). Judge Carrozza, currently investigatingcases of torture, declared that the Valech archives could contribute to ongoing investigations in the same way that the Rettig archives contributed to investigations in cases of the detained-disappeared and politically executed. Judge Carroza expressed concern around the uneven criteria of access to the Truth Commissions' archives. ${ }^{44}$ The issue surrounding the secrecy of the Valech archives and the different access policies should be resolved by appropriate Congress legislation and it remains a pending obligation of the Chilean state. ${ }^{45}$ The political context of the Valech Commissions was radically changed in comparison to the early transition years and thousands of judicial investigations were already ongoing. Therefore, the choice to impede the judicial use of the Valech archives has been contested and challenged since the early days of the release of the Valech I report. As this section showed, despite the more favourable political climate, the main factors that facilitated the use of Valech archives for justice were

\footnotetext{
${ }^{42}$ Interview with Leonardo Urrutia, Head of Memory, Archive and Documentation department, National Institue of Human Rights, NIHR, Santiago, March 2019.

43 The reason behind that decision is that that Valech II archives have a different regime of confidentiality, which do not explicitly establish the prohibition of access to the courts as in case of the Valech I archives.

44 Personal Interview, Judge Carrozza, April 2019.

45 Interview with Leonardo Urrutia, NIHR, Santiago, March 2019.
} 
the persistent mobilisation of the torture survivors, the sustained activism of civil society organisations, and the intervention and motivations of several state actors, including the National Institute for Human Rights, the Comptroller General Office of the Republic (CGR) and the courts.

Beyond their judicial use in cases of torture that are still under investigation, civil society organisations have led a political struggle to gain access to these archives as means of advancing democratisation and expanding the public's ability to confront the past. Since 2013, a collective and a site of memory, called Londres 38, has conducted a vocal campaign called 'No more secret archives' demanding access to all the truth commissions' archives as well as the military and police archives that are still sealed (Londres 38 2019). This campaign formed the beginning of a much broader movement involving other sectors in society that started to challenge state secrecy as a legacy of authoritarianism still present in contemporary Chile and which continues to shield the state from public accountability and transparency. The long battle to gain access to the secret archives in Chile has, over the years, seen many survivors groups mobilising in their struggle to achieve ownership over the past. Different sectors in society are challenging the state's exclusive ownership of the decision on what can be disclosed and when. The public campaign also testifies to the survivors' current demands for their stories to be made public. While the Valech I and II archives seemed initially to have had a more limited impact than other archives documenting state crimes, the secrecy clauses that sealed them have had quite the opposite effect. Not only has it contributed to fuelling the debates in Chilean society on the role and importance of archives, it has also kept the issue of the past alive. The battle to make the archives public has now become one to preserve the collective memory of the country (Bernasconi et al. 2019). Only time will tell what contribution the Valech archives will make in the longstanding battle for truth, justice and memory in Chile.

\section{Archives as Vehicles of Memory}

In the past 10 years, archives are increasingly playing different roles as instruments of 'memory building' around a contested past. A wide range of scholarship has been dedicated to the relationship between archives and memory and the topic is currently at the centre of a very active and lively debate (Acuña Flores et al. 2016; Archivos en Chile: Miradas, Experiencias y Desafios 2016; Da Silva Catela 2002). It is not the intention of this article to discuss this important topic, but it is essential to recognise that the archives analysed in this paper, together with sites of memory and other artistic and cultural forms of expression all form part of the contemporary terrain for renegotiating the past. Archives are performing a role as spaces of reflection and contention, as well as sources of education and knowledge about the history of state repression. More importantly, there is an understanding in society that archives offer a unique heritage that is critical for the reconstruction of the country's historical memory and the strengthening of democracy. 
A testament of this is the incorporation of the archives of the Chilean human rights organisations in its Memory of the World Register in 2003 by UNESCO. This constituted an important acknowledgment and the beginning of a series of awareness-raising initiatives on the importance of the preservation and protection of the archives as well as on the need to provide greater access to these archives.

Most of the historical human rights organisations have donated part or nearly all of their archives to the Museum of Memory. The Museum of Memory and Human Rights was inaugurated in Chile on 11 January 2010 and it has become the most important and well-known site of memory in Chile. Truth Commissions' archives are also physically hosted in the Museum of Memory even though they remain sealed to the public to this date. Truth Commissions' archives contain critical information on many aspects that remain to be investigated such as how the Truth Commissions' members reached their conclusions, how they built the different categories of victims, how they systematised the myriad of sources received, the role played by domestic and external actors, and most importantly what has been left out of the official reports and why. All this information will also allow researchers to compare the work of the two truth commissions with that of former human rights organisations' and how and to what extent their narrative(s) concur or clash. The archives constitute a legacy left by the truth commissions and their permanent status makes them fundamental instruments for the fulfilment of the right to truth. Hence, it is critically important to make the truth commissions' archives public and allow Chilean society to continuously engage with its much-contested past.

Regrettably, there is a big piece missing in the reconstruction of the collective memory around state terrorism as there is currently no access to the security services and armed forces' archives. The lack of availability of information is further intensified by a national law (Law 18.771), which allows the Ministry of Defence and the Armed Forces to eliminate and destroy the documents every 5 years, unlike other public agencies which are required to send their documents to the National Archive. This law has not yet been modified and there is a fear that most of the information documenting state crime has already been destroyed. Therefore, the value of the Vicariate's archives, human rights organisations' archives and the Truth Commissions' archives is enormous since they all have the merit of preserving information that would otherwise be lost forever.

\section{Conclusions}

This article demonstrated that archives have played multiple roles at different points in time during the long transitional path in Chile as tools of truth, justice and reparations, and they are currently playing a crucial role in the construction of the collective memory on the past. Chile has witnessed the establishment of four Truth and Reconciliation Commissions. Hundreds of perpetrators have been convicted and prosecutions are still taking place; different reparation programmes have been implemented and gradually expanded over time; many memorials have been erected including a Museum of Memory and Human Rights. All the above measures and 
processes have strongly benefited from the existence of records and archives that had been adequately preserved and kept.

As the article has shown, the Vicariate archives and other human rights archives were extensively relied upon by the later Truth Commissions to complete their work. Truth Commissions have, in turn, collected thousands of statements from victims, relatives and witnesses, a vast number of records and documents from multiple sources, which, with the passing of time, have played a vital role in enhancing subsequent accountability, reparations and memory efforts in the country. The archives of the Truth Commissions have been used as essential evidence to obtain reparations for the families of the disappeared and the survivors of torture and political imprisonment recognised by the Truth Commissions' reports. Moreover, as shown above, the Rettig archives were used as probative evidence in the belated human rights trials against perpetrators of human rights violations. Furthermore, even though the relationship with justice was initially curtailed, the Valech archives have also been made partially accessible to the courts. Moreover, the Valech archives have been a source of contention within Chilean society for many years, giving rise to intense debates on the role and importance of access to archives and are hence playing a crucial role in the battle for memory.

The article finds that the interaction between archives and transitional justice in Chile has been possible thanks to a combination of factors that this study has analysed and discussed. The study claims that the ways in which archives are collected, filed and systematised together with the aims and goals of documenting are all necessary but not sufficient conditions to determine their future uses. Other factors, including the political context, the intervention and motivations of different actors, the mobilisation of social sectors and timing, played a major role for the activation of archives in the service of transitional justice. For this reason, the findings from the Chilean case study offer a number of important lessons on the relationship between archives and transitional justice.

First, archives do not exist in a vacuum; they are not neutral artefacts and they need the intervention of several factors and interaction with different actors to acquire meaning.

While the manner in which archives were collected, organised, classified and subsequently preserved has contributed towards the future uses to which they have been put, the article demonstrates that archives have acquired life owing to the intervention of additional enabling factors. These include the political context, the role and motivations of the actors that used the archives, the activism of certain sectors withincivil society, the cooperation of state actors and the passage of time. In Chile, a combination of the above factors has enabled the archives to be used as a tool for transitional justice at critical moments during the long transitional period.

The Vicariate archives were activated by the Truth Commission members and staff that were aware of the high value of the work carried out by this institution during the dictatorship. Likewise, in a complex political context, the Catholic Church and other human rights organisations supported the work of the Rettig Commission and made available their archives to this body. The cooperation between state actors and civil society sectors during the earlier phases of the transition facilitated the activation of the human rights archives. Furthermore, as shown in the article, 
given the difficult political climate in which the Rettig Commission was established, its members felt the urgency and importance of their undertaking. Therefore, the commissioners were very detailed and cautious with the information they released in every single case under examination so that the chances of mistakes would be reduced to a minimum. A few years later, the archives so painstakingly created by the Rettig Commission and its follow-up body, the Corporation, were re-discovered and used by the judges who started to investigate the human rights violations that took place under the dictatorship. These records have become one of the most reliable sources of evidence upon which thousands of cases were built against those responsible for the past abuses. Although many other factors also led to the subsequent human rights trials, such trials relied heavily upon the information and documentation that had been collected and filed earlier by the Rettig Commission.

As in the case of the Vicariate archives, the manner in which the documentation was collected and systematised certainly facilitated its subsequent use for prosecutions. However, the article found that it was the changed attitude of the judges in a profoundly different political environment that re-activated the Rettig archives as judicial evidence in later years.

Similarly, the Valech I and II Commissions produced an extensive amount of evidence and records documenting the huge impact of torture and political imprisonment; yet, as the section on the Valech archives showed, it required strong activism by survivors' groups, extensive social mobilisation and the participation of several state actors for survivors to gain access to their files and testimonies, and for judges to gain partial access to these archives. In this way, the Valech archives also could be unexpectedly activated for judicial use in later years.

Second, the Chilean case shows that time is an important factor as the archives have been used multiple times over the longer term; while the institutions that create archives are temporary and limited, the archives and the records they leave behind may serve multiple purposes in the future, often in unprecedented ways. Nobody had anticipated that the documentation so painstakingly collected by civil society organisations during the dictatorship would acquire multiple roles in protecting victims' rights many years after they were created. Likewise, the archives of the Rettig Commission acquired a probative value in the human rights trials many years after they had been created. Furthermore, heated debates around the secrecy of the Valech Commissions' archives has provided new opportunities for social and political actors to challenge the issue of the secrecy of state archives as the starting point of a much broader campaign to obtain more transparency and accountability from Chilean institutions. As shown in the article, time is an important factor in that archives can be activated and re-activated multiple times and acquire different meanings and purposes.

Finally, archives have over time revealed themselves to be powerful instruments against the wall of secrecy erected by state institutions on many occasions throughout the transition. Since the beginning of the transition, civil society actors have constantly demanded and negotiated with the state for the creation and expansion of transitional justice mechanisms in order to deal with the past and to respond to the needs of the thousands of victims that the dictatorship had left behind. While the state has on many occasions attempted to close the book on the past, mounting evidence revealed through testimonies, records and archives has proven to be a 
means of resistance against silence, revisionism and closure. While truth commissions have been regarded several times as closing chapters, the archives that constitute a permanent legacy have contributed in multiple ways to the development of other mechanisms to deal with the past. The Chilean case demonstrates the importance of preserving the archives of truth commissions for the purpose of later prosecutions, making reparations and memorialisation. While the literature has devoted much attention to the archives created by human rights organisations to advance truth commissions, trials and memory, further research is needed to systematically compare and explore the multiple uses of truth commissions' archives after the truth commissions have completed their work. The use of truth commissions' archives as evidence in prosecution deserves further investigation as it has become a growing practice at both the national and international levels to prosecute international crimes, especially in the Latin American region. It is equally important to further investigate the relationship between truth commissions' archives and 'memory building'. Human rights archives and truth commissions' archives are playing a crucial role in confronting and renegotiating the past, becoming an essential vehicle of memory. Archives uniquely preserve not only victims' voices and their sorrow but also their stories of political struggle and activism, usually omitted from the mainstream narratives on the past violence. This makes them an essential means of integrating multiple and diverse experiences and narratives into society's collective memory and of providing safeguards against historical revisionism and future negationism. To conclude, the multiple roles archives have acquired over time in Chile demonstrates that records are powerful instruments and through appropriate channels of activation the power of archives will eventually become manifest.

\section{Funding Open Access funding provided by the IReL Consortium}

Open Access This article is licensed under a Creative Commons Attribution 4.0 International License, which permits use, sharing, adaptation, distribution and reproduction in any medium or format, as long as you give appropriate credit to the original author(s) and the source, provide a link to the Creative Commons licence, and indicate if changes were made. The images or other third party material in this article are included in the article's Creative Commons licence, unless indicated otherwise in a credit line to the material. If material is not included in the article's Creative Commons licence and your intended use is not permitted by statutory regulation or exceeds the permitted use, you will need to obtain permission directly from the copyright holder. To view a copy of this licence, visit http://creativecommons.org/licen ses/by/4.0/.

\section{References}

Acuña M et al. (2016) Archivos y memoria de la represión en América Latina (1973-1990). LOM ediciones.

Alberch I Fugueras R (2008a) Archivos y derechos humanos.Trea.

Alberch I Fugueras R (2008b) Rights Memory Truth and Justice: Archives for Human Rights. In: Archivos Memoria y Derecho a la Verdad: Memorias Seminario Internacional Bogota, Colombia, 26-28 November; available at https://www.bogota.gov.co/archivo/libreria/pdf/MEMORIAS_DD_HH_ FINAL.pdf

Americas Watch (1991) Human Rights and the 'Politics of Agreements'. New York: Americas Watch. 
Archivos en Chile: Miradas, Experiencias y Desafios. (2016). https://www.patrimoniocultural.gob.cl/614/ articles-62607_archivo_01.pdf.

Barahona de Brito A (1997) Human Rigths and Democratization in Latin America, Chile and Uruguay. NY: OUP.

Baumgartner E, Hamber B, Jones B, Kelly G, Oliveira I (2016) Documentation, Human Rights and Transitional Justice Journal of Human Rights Practice 8 (1):1-5

Bernasconi O (ed) (2019) Resistance to Political Violence in Latin America, Documenting Atrocity. Springer.

Bernasconi O, Lira E (2019) Making State Violence Visible: Documenting, Investigating and Denouncing Atrocities. In: Bernasconi O (ed) Resistance to political violence in Latin America: Documenting Atrocity. Springer.

Bernasconi O, Mansilla D, Suárez R. (2019) Las Comisiones de la Verdad en la Batalla de la Memoria: Usos y Efectos Disputados de la Verdad extrajudicial en Chile Colombia Internacional 97:27-55.

Blanco-Rivera JA (2012) Archives as agents of accountability and justice: an examination of the national security archive in the context of transitional justice in Latin America. PhD Thesis. University of Pittsburgh

Campos J, Sáez L. “Contra el Velo del Secreto y el Silencio”. La Demanda por la Desclasificación de los Archivos de la Comisión Valech I en Chile: La Experiencia del Equipo de Desclasificación Popular (2015-2016) http://conti.derhuman.jus.gov.ar/2016/11/seminario/mesa_24/campos_saezfuentealba_ mesa_24.pdf.

Caswell M (2010) Khmer Rouge archives: accountability, truth, and memory in Cambodia Archival Science $10(1): 25-44$

Caswell M (2014) Defining human rights archives: introduction to the special double issue on archives and human rights. Archival Science, 14 (3-4):207-213

Centro de Estudios Públicos (1991) Respuesta de la Corte Suprema al Informe de la Comisión Nacional de Verdad y Reconciliación Estudios Públicos 42:237-250

Collier S and Sater W.F., (1999) A History of Chile, 1808-2002. New York: Cambridge University Press.

Comision Asesora Presidencial (2011) Informe de la Comision Presidencial Asesora para la Calificacion de Detenidos Desaparecidos, Ejecutados Politicos y Victimas de Prision Politica y Tortura.

Corporacion Nacional de Reparacion y Reconciliacion (1996) Informe sobre Calificacion de Victimas de Violaciones de Derechos Humanos y de la Violencia Politica. Santiago, Chile

Da Silva Catela L (2002) El mundo de los archivos. In: Da Silva Catela L, Jelin E (eds) Los Archivos de la Represion: Documentos, Memoria y Verdad. Madrid: Siglo XXI.

Da Silva Catela L, Jelin E (2002) Los Archivos de la Represión: Documentos, Memoria y Verdad vol 4. Siglo XXI de España Editores.

Decree Law N.5 (11 September 1973).

Duff WM, Flinn A, Suurtamm KE, Wallace DA (2013) Social justice impact of archives: a preliminary investigation. Archival Science 13 (4):317-348

Ensalaco M (2000) Chile under Pinochet: Recovering the Truth University of Philadelphia, PA: Pennsylvania Press.

Ferrara A (2015) Assessing the Long-term Impact of Truth Commissions. The Chilean Truth and Reconciliation Commission in Historical Perspective London: Routledge.

Fuentes CA (2000) After Pinochet: Civilian Policy toward the Military in the 1990s Chilean Democracy Journal of Interamerican Studies and World Affairs 42 (3) :111-142

Harris V (2002) The Archival Sliver: Power, Memory, and Archives in South Africa Archival Science 2 (1):63-86

Harris V (2014) Antonyms of our Remembering Archival science 14 (3-4):215-229

Hau B, Lessa F, Rojas H (2019) Registration and documentation of state violence as judicial evidence in human rights trials. In: Bernasconi $\mathrm{O}$ (ed) Resistance to political violence in Latin America, documenting atrocity. Springer

Instituto Nacional de Derechos Humanos INDH (2014) Informe Anual. Santiago de Chile, Chile.

International Council on Archives (2012) Committee on best practices and standards working group on access, 'Principles of Access to Archives'. https://www.ica.org/sites/default/files/ICA_Access-princ iples_EN.pdf

Jimerson R (2007) Archives for All: Professional Responsibility and Social Justice. The American Archivist 70 (2):252-281

Johansson M, Lopez L (2019) Del repertorio al archivo: performatividad testimonial y alianzas colectivas e la labor de las asistentes sociales de la Vicaria de la Solidariedad Universum (Talca) 34:119-145 
Ketelaar E (2001) Tacit Narratives: the Meanings of Archives. Archival Science 1 (2):137-139

Ketelaar E (2008) Archives as Spaces of Memory. Journal of the Society of Archivists 29 (1):9-27

Labbé MF, Tagle MS. 2019 Conceptos y Prácticas en torno a la Violación de los Derechos Humanos en Chile: La Vicaría de la Solidaridad, 1976-1983. Historia 396. 9 (1):125-64.

Lira E (2017) The Chilean Human Rights Archives and Moral Resistance to Dictatorship International. Journal of Transitional Justice 11 (2):189-196

Londres 38 No mas Archivos Secretos. https://www.londres38.cl/1937/w3-propertyvalue-37543.html. 2019

Lowden P (1995). Moral opposition to Authoritarian Rule in Chile, 1973-90. Springer.

Meza Lopehandia G M (2016) El caracter secreto de los antecedentes de la comision Valech. Biblioteca del Congreso Nacional de Chile (BCN). https://bit.ly/3pzQPra.

Fries L (2015) Columna de Opinion Verdad y Justicia para las Victimas de Prision Politica y Tortura. http://bcn.cl/1t4nt.

Nora P (1989) Between Memory and History: Les Lieux de Mémoire Representations 26: 7-24

Otano R (2006) Nueva Conica de la Transicion. 2 edn. Santiago Chile. LOM Ediciones.

Peterson T.H. ( 2005) Final Acts: A Guide to Preserving the Records of Truth Commissions Washington, DC: Woodrow Wilson Center Press.

Quintana AG (2009) Archival Policies in the Protection of Human Rights. An updated and fuller version of the report prepared by Unesco and the International Council on Archives (1995), concerning the management of the archives of the state security services of former repressive regimes. https://www. ica.org/en/archival-policies-in-the-protection-of-human-rights-0.

Rabkin R (1992) The Aylwin Government and 'Tutelary' Democracy: a concept in search of a case? Journal of Interamerican Studies and World Affairs 34:119-184

Report of the Chilean National Commission on Truth and Reconciliation (1993). Center for Civil and Human Rights and Notre Dame Law School, the University of Notre Dame Press

Schwartz JM, Cook T (2002) Archives, records, and power: the making of modern memory. Archival Science 2 (1):1-19

Smith BH (1986) Old allies new enemies: the catholic church as opposition to military rule in Chile (1973-1979). In: Military rule in Chile: dictatorship and opposition. Baltimore MD John Hopkins, University Press.

Stern S J (2010) The Memory Box of Pinochet's Chile, 3 vols. London: Duke University Press.

Strauss A (2015) Treading the Ground of Contested Memory: Archivist and Human Rights Movement in Chile. Archival Science 15 (4):369-397

Swisspeace Archives and Dealing with past project http://archivesproject.swisspeace.ch

Comision Nacional Prision Politica y Tortura (2004) Informe Comisión Nacional Sobre Prisión Política y Tortura. Santiago Chile.

UNHCHR Updated Set of Principles for the Protection and Promotion of Human Rights through Action to Combat Impunity (E/CN.4/2005/102/Add.1), 2005.

Universidad Alberto Hurtado (2017) Guia de archivos de memoria y derechos humanos en Chile. https:// drive.google.com/file/d/0B7drZJJ_NeStOXBwbWNtZ1ZLd2c/view.

Vergara Low MP (2012) Los Archivos de los Desaparecidos en Chile Arch-e/revista Andalusa de Archivos 5:225-238

Weld K (2014) Paper Cadavers: the Archives of Dictatorship in Guatemala. Duke University Press

Valenzuela A and Constable P (1991). A Nation of Enemies: Chile under Pinochet. New York: W. W. Norton.

Wright T C (2007). State Terrorism in Latin America: Chile, Argentina and International Human Rights. Lanham, MD: Rowman \& Littlefield Publishers.

Publisher's Note Springer Nature remains neutral with regard to jurisdictional claims in published maps and institutional affiliations. 